\title{
AN INVESTIGATION OF LISTENING COMPREHENSION STRATEGIES USED BY SIXTH SEMESTER STUDENTS OF ENGLISH EDUCATION STUDY PROGRAM AT UNIVERSITY OF BENGKULU
}

\author{
Afrian Reastu Prayogi \\ Universitas Bengkulu \\ afrian4196@gmail.com \\ Elfrida \\ Universitas Bengkulu \\ mrs.elfrida@gmail.com \\ Mei Hardiah \\ Universitas Bengkulu \\ mei_bungsu@yahoo.co.id
}

\begin{abstract}
ABSTRAK
Penelitian ini bertujuan untuk mengetahui strategi komprehensi menyimak yang digunakan oleh mahasiswa semester enam Program Studi Pendidikan Bahasa Inggris di Universitas Bengkulu. Subyek dalam penelitian ini adalah seluruh mahasiswa semester enam Program Studi Pendidikan Bahasa Inggris tahun akademik 2017/2018. Penelitian ini menggunakan metode kuantitatif deskriptif dan data dikumpulkan dengan menggunakan kuesioner sebagai instrumen. Kuesioner tersebut terdiri dari 35 pernyataan yang mewakili penggunaan strategi komprehensi menyimak dari strategi kognitif, metakognitif, dan sosioafektif. Penelitian ini menggunakan Statistical Package for Social Sciences (SPSS) versi 22 untuk menganalisis data. Skema peringkat Oxford (1990) untuk penggunaan strategi digunakan untuk menentukan kategori dari penggunaan strategi komprehensi menyimak. Hasil analisis data menunjukkan bahwa mahasiswa menggunakan strategi kognitif, metakognitif, dan sosio-afektif dalam komprehensi menyimak. Penggunaan strategi kognitif adalah yang tertinggi dalam komprehensi menyimak dengan nilai rata-rata 3.54 (tinggi), diikuti oleh strategi sosio-afektif dengan nilai rata-rata 3.43 (sedang) dan strategi metakognitif dengan nilai rata-rata 3.4 (sedang). Dari hasil tersebut, dapat disimpulkan bahwa mahasiswa sebagian besar menggunakan strategi ketika mengerjakan tugas menyimak di kelas, dengan menggunakan kemampuan leksikal dan gramatikal serta latar belakang pengetahuan untuk memahami materi-materi dalam menyimak.
\end{abstract}

Kata Kunci: strategi komprehensi menyimak, strategi kognitif, strategi metakognitif, strategi sosio-afektif. 


\begin{abstract}
This research aims to find out the listening comprehension strategies used by sixth semester students of English Education Study Program at University of Bengkulu. The subject of this research is all sixth semester students of English Education Study Program in academic year $2017 / 2018$. This research was using descriptive quantitative as the methodology and the data was collected by using questionnaire as the instrument. The questionnaire consisted of 35 items which represent the use of listening comprehension strategies from cognitive, metacognitive, and socio-affective strategies. This research uses Statistical Package for Social Sciences (SPSS) version 22 to analyze the data. Oxford's (1990) rating scheme for strategy use was used to determine the category of listening comprehension strategies use. The result of data analysis shows that students use cognitive, metacognitive, and socioaffective strategies in listening comprehension. Cognitive strategy was used as the most highly use of strategies in listening comprehension with the mean score 3.54 (high), followed by socio-affective strategy with the mean score 3.43 (moderate) and metacognitive strategy with the mean score 3.4 (moderate). From the results, it is concluded that students are using strategies mostly when doing a listening task at the classroom, by using the lexical and grammatical competences also background knowledge to understand the listening materials.
\end{abstract}

Keywords: listening comprehension strategies, cognitive strategies, metacognitive strategies, socio-affective strategies.

\section{INTRODUCTION}

The main purpose of learning a language is to be able to communicate. In English learning process, listening is the important process of learning. It is a skill which enables language learners to receive and interact with language input and facilitates appearance of other language skills (Vandergrift \& Goh, 2012). When people do not have good listening competences, they may get problems when communicating, such as misunderstanding. For those reason, it is very important to have a good listening skill. A study conducted by Emanuel et al. (2008) revealed that undergraduate students spend $55.4 \%$ of their time listening, followed by $17.1 \%$ reading, $16.1 \%$ speaking, and $11.4 \%$ writing.

In listening process, students are often faced by some problems. The problems that may hinder listening comprehension are different structure of phonemes in the target language, lack of understanding intonation and stress, noise, unfamiliar vocabularies, fatigue, and different accent (Ur, 1984). According to Wilson (2008) there are four general categories of difficulties in listening, they are characteristics of the message, the delivery, the listener, and the environment. In order to overcome those problems, learners need to develop techniques known as listening strategies.

O'Malley and Chamot (1990) pointed out that listening strategies are categorized into three groups, they are cognitive, metacognitive, and socioaffective strategies. Cognitive strategies are the strategies that students use to finish an immediate task, such as finding out the topic before listening to predict the contents. Metacognitive strategies are the strategies that related to learning 
by using steps by steps, from planning, monitoring, and evaluating. It is involved in the aspect of before listening, while listening, and after listening. Socioaffective strategies are the strategies that concerned on students' interaction with other people and control of self-emotion, such as asking feedback to others about their listening performance or motivate ourselves to improve the ability.

The meta-cognitive strategy was a kind of self-regulated learning, which include the attempt to plan, check, monitor, select, revise, and evaluate, etc. (Gilakjani \& Ahmadi, 2011). There are four wide aspects in metacognitive strategies, which include selective attention, planning, monitoring, and evaluation (O'Malley \& Chamot, 1990). The cognitive strategies are related to comprehending and storing input in working memory or long-term memory for later retrieval, which are investigated from the aspects of bottom-up strategies and top-down strategies (Gilakjani \& Ahmadi, 2011). According to Richards (2008), bottom-up strategies refer to use incoming input such as lexical and grammatical competence as the basis for understanding the message, while topdown strategies refer to use background knowledge to understand the meaning of the message. For socio-affective strategies, O'Malley \& Chamot (1990) stated that this strategy involves interaction with other people and control of self-emotion. This strategy includes cooperation, questioning for clarification, and self-talk which can be useful for listening comprehension.

At University level, students of English Education Study Program take listening subject. As compulsory subject, students take listening subject at the second semester until the fourth semester. The listening subject is divided into three, they are listening for mini talk, listening for longer conversation, and listening for lecture. At the third year of education, students have to complete those listening subjects.

In this research, the researcher would like to conduct a research about students' strategies in listening comprehension. The subject of this study will be the sixth semester students of English Education Study Program at 2017/2018 academic year. Those students have completed all listening subject. Most of them have high score in listening subject. The average students got B score. By doing this research, it will reveal what strategies they use when doing listening comprehension. The result can give benefit for others to implement the strategies when doing listening comprehension activity to increase their skill.

The previous explanations become the researcher's background in conducting the research. The researcher would like to investigate the listening comprehension strategies used by sixth semester students of English Education Study Program at University of Bengkulu.

\section{METHOD}

This research used descriptive quantitative method because the gathered data will be described in form of number. Johnson \& Christensen (2004) stated that quantitative research was kind of research that relies on the collection of quantitative data. The form of report is in statistical form.

The researcher used this kind of method because to collect the data, likert-scale questionnaire is used. The data collected from the questionnaire is analyzed using statistical analysis and a formula is used to identify the data.

The subject of this research is the sixth semester students of English Education Study Program at University of 
Bengkulu. The number of overall subject is 74 students from two classes, as described in the following table.

Table 1. The Distribution of Subject

\begin{tabular}{|c|c|c|}
\hline No & Class & Number of Students \\
\hline 1 & A & 38 \\
\hline 2 & B & 36 \\
\hline \multicolumn{2}{|c|}{ Total } & 74 \\
\hline
\end{tabular}

The totals of 74 students have taken listening subject from the previous semesters. They have experienced on listening subject from the low until high level of study. The research subjects also have different ability in listening, so there may be some variations in the use of learning strategies.

In this study, the researcher used questionnaire as an instrument. Questionnaire is a set of statement in written form to gather information from the respondents of the research. The instrument used consist of 35 items which represent the use of strategy in listening comprehension, from cognitive, metacognitive, and socio-affective strategy. Then, it is also provided a question intended to see whether there are any other strategies that is not mentioned in the questionnaire items which are used by students.

The instrument that is used in this study is Listening Strategies Use Questionnaire (LSUQ) which is adapted from Nowrouzi, et al. (2014). It consist statement that related to personal attitudes toward the use of listening comprehension strategies. The researcher gave explanation to the respondents about listening comprehension strategies before distributing the questionnaire to make them understand what they will do after receiving the questionnaire. The statements on the questionnaire are divided into three groups: cognitive, metacognitive, and socio-affective strategies. It is provided with likert-scale.
Each statement is followed by scale rating from 1 to 5 which indicate: 1=never, 2=rarely, 3=sometimes, 4=usually, $5=$ always.

Before distributing the questionnaire, the researcher does some preparation. The questionnaire was checked to certain that there are no confusing words or phrase which may be encountered by the respondents. The researcher used common words which are easy to be understood by the respondents. Then, the questionnaire was copied as many as the number of the respondents.

The questionnaire is validated before it is ready to be distributed. The questionnaire was validated by the expert in listening subject. The expert read and checked each item on the questionnaire, which consist of 32 items, then made some changes on it. Then, the questionnaire that has been validated consist of 35 items.

After the questionnaire is ready to be administered, the researcher came upon the respondents to collect the data. Firstly, the researcher gave the explanation about listening comprehension strategies and about the questionnaire. Then, the researcher distributed the Listening Strategies Use Questionnaire (LSUQ) to each respondent and asked them to answer each statement based on their personal attitudes toward listening comprehension strategies. After the respondents were finished, the researcher took back the questionnaire and collected them to be analyzed.

After collecting the data, the next step this research is analyzing the data gathered. It is analyzed by using statistical method. Therefore, the data was submitted in numerical forms through the assist of computer software. It is analyzed using IBM SPSS Statistics 
software version 22 . The formulas used in analyzing the data were using mean and percentage as follows:

1. Mean

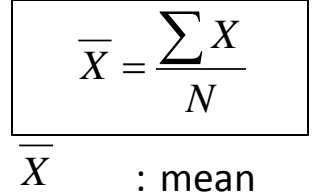

$$
\begin{aligned}
& \sum X \text { : sum of all data } \\
& \text { values } \\
& N \quad \text { : number of data }
\end{aligned}
$$

2. Percentage

$$
\begin{array}{ll}
\hline P=\frac{F}{N} \times 100 \\
P \quad: \text { percentage } \\
F \quad: \text { frequency of } \\
\text { responses } \\
N \quad: \text { number of } \\
\text { respondents }
\end{array}
$$

To determine the use of listening comprehension strategies, the researcher used Oxford's (1990) rating scheme for strategy use. The rating scheme of strategy use category is on the following table.

Table 2. Rating Scheme for Strategy Use

\begin{tabular}{|c|c|}
\hline Mean & Category \\
\hline $1.0-2.4$ & Low \\
\hline $2.5-3.4$ & Moderate \\
\hline $3.5-5.0$ & High \\
\hline
\end{tabular}

\section{RESULT AND DISCUSSION}

\section{Result}

In this section, the researcher presents the result of the research that has been conducted. The result is divided into three types of listening comprehension strategies use. Additionally, it provides the additional result of strategy use that is obtained from the additional question.

First, the total average of the mean score for cognitive strategies use was 3.54 which is categorized as "High". It indicates that students were highly use cognitive strategies in listening comprehension, since the category for the use of this strategy was at high predicate.

Second, the total average of the mean score for metacognitive strategies use was 3.4 which is categorized as "Moderate". It indicates that students were sometimes use metacognitive strategies in listening comprehension, but do not give much attention on it, since the category for the use of this strategy was moderate.

Third, the total average of the mean score for socio-affective strategies use was 3.43 which is categorized as "Moderate". It indicates that students were sometimes use socio-affective strategies in listening comprehension, but do not give much attention on it, since the category for the use of this strategy was moderate.

From the additional question, there were 8 students who add some additional strategies in listening comprehension. It was obtained that from the total of eight students who write additional strategies in listening comprehension, there were seven students add strategies which are categorized into cognitive strategy. Besides, one student adds a strategy which is categorized into socio-affective strategy.

Based on the data obtained from the questionnaire, the table below summarizes the students' use of listening comprehension strategies.

Table 3. Summary of Listening Comprehension Strategies Use

\begin{tabular}{|c|c|c|c|}
\hline No & Strategies & Mean & Category \\
\hline 1 & Cognitive & 3.54 & High \\
\hline 2 & Metacognitive & 3.4 & Moderate \\
\hline 3 & Socio-Affective & 3.43 & Moderate \\
\hline
\end{tabular}

Based on the table above, it can be seen that students use all the strategies, but there are any differences in the frequency of using those 
strategies. Cognitive strategies use was categorized as "High" with the mean score 3.54, while metacognitive and socio-affective strategies use was categorized as "Moderate" with the mean score 3.4 for metacognitive strategies and 3.43 for socio-affective strategies. It can be concluded that students use cognitive strategies the most frequently, followed by socioaffective strategies, then metacognitive strategies.

\section{Discussion}

Cognitive strategies were strategies that students used to finish an immediate task. Beside of that, it also involves the aspects such as inference, elaboration, summarization, translation, transfer, and repetition. The result of this study has shown that students used this strategy in "High" predicate. This is showing that students of sixth semester were often doing strategy such as using inference, elaboration, summarization, translation, transfer, and repetition.

Metacognitive strategies were strategies that include the aspect of planning, monitoring and evaluating in listening comprehension. The result of this study has shown that students used this strategy in "Moderate" predicate. It shows that students were sometimes using this kind of strategy by paying attention to the aspect of before listening, while listening, and after listening.

Socio-affective strategies were strategies that related to interaction with others and the aspect such as lowering their anxiety. The result of this study has shown that students employed this strategy with "Moderate" predicate. It shows that students were sometimes using strategies in listening comprehension by interacting with others and controlling their self-emotion.
The result showed that the most strategies frequently used by students were cognitive strategies, followed by socio-affective strategies and metacognitive strategies. The result was in line with Abdalhamid (2012) which revealed that students were using cognitive strategies as the most contributed strategies in listening comprehension, followed by socioaffective strategies and metacognitive strategies. Furthermore, Nowrouzi et al. (2014) reported from their findings of listening comprehension strategies used by Iranian EFL Students which investigated 100 students, that cognitive strategies were used most frequently with the mean score 2.44. However, socio-affective strategies were categorized as the lowest level of listening comprehension strategies use with the mean score 2.20, and for metacognitive strategies, the mean score was 2.36.

Besides the result above, there were some respondents who add some additional strategies in listening comprehension. There were 8 respondents who write the additional strategies in the question. The question was asking about additional strategy that the respondent used when doing a listening comprehension. From the result, it was obtained that mostly, the students' answer about another strategy they used in listening comprehension was categorized into cognitive strategy. From eight students, seven students were writing listening comprehension strategy which is involved into cognitive strategy. They include strategy such as using visualization, repetition, elaboration (using previous knowledge), inference, and note-taking. While, one another student was writing a strategy which is involved into socio-affective strategy. The strategy is reducing anxiety by trying to 
close his or her eyes to make the student more focused on the listening material.

The result of this result can be used by others as the references for using strategies in listening comprehension. Since the subject of this research was categorized as good in listening comprehension, other students can use the strategies which have been described from the results as the reference. However, every student has their own learning style. Although most of the students in this research used cognitive strategy highly, it is uncertain that cognitive strategy was the best strategy in listening comprehension. Other students may use other strategies that are considered as good for them, because of the different learning style of each student.

For the further researcher that will conduct the research in the same field, they can develop this research and use it as the reference. The further researcher may conduct the correlational study, such as the correlation between listening comprehension strategies and the listening achievement, or to conduct this research at different subject or location.

\section{CONCLUSION AND SUGGESTION \\ Conclusions}

This research is conducted to investigate the listening comprehension strategies used by sixth semester students of English Education Study Program at University of Bengkulu. The listening comprehension strategies were divided into three categories based on the theory from O'Malley and Chamot (1990), they are cognitive strategies, metacognitive strategies, and socio-affective strategies.

The results show that cognitive strategy got the mean score 3.54 which is categorized as High. While, metacognitive strategy got the mean score 3.4
(Moderate) and socio-affective strategy got the mean score 3.43. From those results, it indicated that cognitive strategy was used the most, followed by socio-affective strategy and metacognitive strategy.

From the results, the students of sixth semester were using cognitive strategy in performing listening comprehension with the highest predicate. It is concluded that students were using strategy mostly when they do a listening task at the classroom, such as predicting, inference, note-taking, translation, elaboration, and repetition. Those strategies were using the lexical and grammatical competences also background knowledge in understanding the listening materials.

\section{Suggestions}

Regarding to this research, there are some suggestions given by the researcher as follows:

In practical contribution, or the lecturer, this research could give feedback and information in teaching and learning about listening comprehension strategies. It could be a reference for the lecturer to give explanation about using strategies in listening comprehension to the students. The lecturer can give information about the strategies to the students, then the students can apply those strategies. From that, it could improve students' performance in listening comprehension.

For the students, this research will be expected to improve their awareness of using strategies in listening comprehension. This research could be a reference for them to use strategies in listening comprehension. By using the strategies, it is expected that students' competences in listening comprehension will be improved. 
For the future researcher, this research can be used as a reference to conduct a research with the same topic. The future researcher might do an investigation of strategies which is used by successful learners to see whether there are any different results. The future researcher also can develop the research such as do a correlation with the other variables or conduct the research with the different subject or location. Furthermore, the future researcher also can develop the research with different language skills with the same theory of learning strategies.

Theoretically, this research is expected to help in finding out the strategies used by students in listening comprehension.

\section{REFERENCES}

Abdalhamid, F. (2012). Listening Comprehension Strategies of Arabic-Speaking ESL Learners. Master's Thesis, Colorado State University, Fort Collins, Colorado.

Emanuel, R., Adams, J., Baker, K., Daufin, E., Ellington, C., Fitts, E., et al. (2008). How College Students Spend Their Time Communicating. International Journal of Listening, 22(1), 13-28.

Gilakjani, A. P., \& Ahmadi, M. R. (2011). A Study of Factors Affecting EFL Learners' English Listening Comprehension and the Strategies for Improvement. Journal of Language Teaching and Research, 2(5), 977-988.
Johnson, R. B., \& Christensen, L. B. (2004). Educational Research: Quantitative, Qualitative, and Mixed Approach. Boston: Allyn and Bacon.

Nowrouzi, S., Sim, T. S., Zareian, G., \& Nimehchisalem, V. (2014). Selfperceived Listening Comprehension Strategies Used by Iranian EFL Students. International Journal of Applied Linguistics \& English Literature, $3(6), 35-41$.

O'Malley, J. M., \& Chamot, A. U. (1990). Learning Strategies in Second Language Acquisition. Cambridge: Cambridge University Press.

Oxford, R. L. (1990). Language Learning Strategies: What Every Teacher Should Know. Boston: Heinle \& Heinle Publishers.

Richards, J. C. (2008). Teaching Listening and Speaking: From Theory to Practice. Cambridge: Cambridge University Press.

Ur, P. (1984). Teaching Listening Comprehension. Cambridge: Cambridge University Press.

Vandergrift, L., \& Goh, C. C. (2012). Teaching and Learning Second Language Listening: Megacognition in Action. New York: Taylor \& Francis.

Wilson, J. J. (2008). How to Teach Listening. Harlow: Pearson Education Limited. 